\title{
WEST AFRICAN SHORTHORN BREEDERS ASSOCIATION IN THE SABOBA-CHEREPONI DISTRICT OF GHANA: FORMATION, EXPECTATIONS AND PERCEPTIONS OF MEMBERS IN PARTICIPATORY BREED DEVELOPMENT
}

\author{
N. Karbo ${ }^{6}$, E. O. Otchere ${ }^{7}$, D. Millar ${ }^{8}$, J. Bruce, M. B. T. Zuri, \\ and H. K. Dei
}

\section{Abstract}

The data presented in this paper are from surveys carried out in five communities namely Chegbani, Konkonzoli, Kuntuli, Nasom and Sambuli to assess aspects of the expectations and perceptions of West African Shorthorn Breeders Association (WASHBA) members in the Saboba-Chereponi District in the Northern Region of Ghana. The West African Shorthorn (WASH) is the dominant cattle breed in Ghana but the biggest threat to the WASH is from the numerically strong but ill - adapted Zebu, which is used for crossbreeding and is eroding the WASH genes. The WASH now constitutes only about $46 \%$ of the national herd. The Ministry of Food and Agriculture (MoFA) and the Animal Research Institute (ARI) adopted the Open Nucleus Breeding Scheme for animal breeding. This decision was based on the fact that cattle herds in Ghana are generally small and basic infrastructure for recording of performance and pedigree are non-existent. The adopted nationally accepted ONBS and the formation of WASHBA, thus involving community members in the development process, provides opporiunities to halt the observed

\footnotetext{
${ }^{5}$ The authors are greatly indebted to the Director of the CSIR-Animal Research Institute, the Saboba-Chereponi District Assembly and the Regional Office of the FAO, Accra for their financial and moral support, which made this study possible. The authors are also grateful to the WASHBA group members in Chegbani, Kuntuli, Kunkonzoli Nasom and Sambuli for their time in the organization and cooperation with the steady teams.

${ }^{6}$ Dr. N. Karbo and Dr. J. Bruce are researchers in the Animal Research Institute, Tamale

${ }^{7}$ Prof. E. O. Octhere, M.B.T. Zure and H.K. Dei lecture in the Dept of Animal Science, University for Development Studies, Nyankpala Campus.

${ }^{8}$ Dr. D. Millar lectures in the Depts of Planning, Land Economy and Rural Development and Agricultural Economics and Extension, University for Development Sudies
} 
genetic erosion of the WASH. This is perceived in its conservatic? and improvement for integration in the farming systems as a means of reducing rural poverty. In a decade, five WASHBA groups emerged and are functional with similar formative experiences. Expectations from some WASHBA members were quite high and missed the principle of endogenous development. However, many of the groups perceived having gained some benefits from the WASH cattle. The role of community based groups as partners in Research and Development to move rural agriculture forward is established in this study.

Key Words: Breeds, Cattle, Livestock, Research. Groups Re/ production, Development

\subsection{Introduction}

In advanced economies, different breeds were evolved and sustained by breed associations. The objectives of the breed associations had been (1) to preserve the purity of the breed; (2) encourage further improvement of the breed; (3) to advertise and promote the breed and (4) seek the material well being of association members. There are no livestock breed associations in Ghana. The Animal Research Institute of the Council for Scientific and Industrial Research (ARI-CSIR), in collaboration with rearers of the WASH, has initiated the WASHBA in the Saboba-Chereponi District. The primary objective for the formation of WASHBA is to conserve and prevent genetic erosion as well as improve upon the productivity of the WASH in an integrated farming system.

A baseline diagnostic survey of the district revealed that in addition to crop farming, the area was a WASH enclave in the Northern Region (Otchere, Karbo, Addo-Kwafo, Aning, Aboe, Clottey \& Asare 1997). In that study, it was observed that formal group formation for economic ventures was absent and not well understood. A follow up study on group formation and wealth accumulation confirmed this (Millar, Karbo, Bruce \& Otchere 
1998). Wr further discovered that there cxisted informal or indigenous groups based on lineage and settement patteros. Some of these have been rekindled around the Fulani for cattle tendering purposes with potential for development into formal groups. Since then other studies have been conducted in the area involving the WASH in the rarming systems (Aning, Karbo, Doku \& Orchere 1999; Adu, Karbo, Addo Kwato \& Otchere 1999). Zuri (2003) reported on the managenent systems, holding sizes, herd structures, off takes and reproductive performance of the WASH with traditional rearers in the area.

This cumrent report seeks to bring to the fore a synthesis of cxperiences from surveys conducted in the WASH catte enclave of Sabobar-Chereponi District from a development perspective, drawing on the socio-economic and cultural aspects of the breed, the energing WASHBAs and their group dynamics.

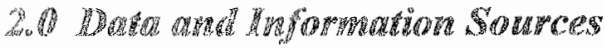

A large wroportion of the data was generated from results of surveys conducted in the Saboba-Chereponi District for the past decade. Various mowhidisciphinary teams were used in the surveys. Wrominewt anong the tools used in surveys for data sourcing und huded famer group discussions, key informal interviews, ranking and by sompoing direct field observations. Relevant secondary hilerabure sources served for crosschecking, comparison and discussion puposes.s.

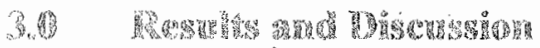

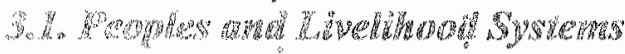

The poputation of the Saboba-Chereponi District is about 94,215 (1010), 2002). The main cturne groups in the District are the Konkowna, Whe Chokosi and the Dagomba The Konkomba group is the magnity. Tradibual awhority, religion and makets have been

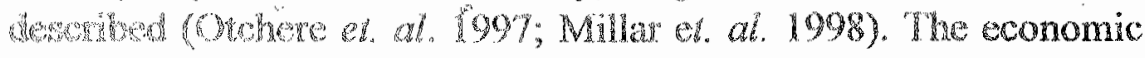


activity in the study area is mainly a sedentary mixed crop-livestock production system. Crop production is the major livelihood but the farmers engage in the livestock enterprise as the major cash income source. Livestock and powltry rearing are very important farming activities and constitute a bank from which sales are made to finance the purchase of food crops when the barns are depleted or when there is a need for cash to meet other obligations such as the payment of school fees, hospital bills, financing of a marriage and funeral ceremonies (Otchere et. al. 1997; Millar et. al. 1998).

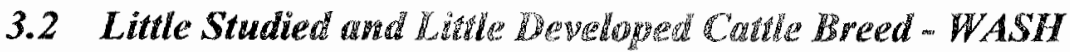

i. The WASH is a humpless bresd of cattle. There are two types:

ii. The larger Savannah (giant) WASH is found in northern Ghana

iii. The smaller (dwarf) WASH is found in the forest and coastal areas.

Both types are small in size, short limbed, with varying coat colours and shape of horns (Anyorikeya 1992). The dwarf variant is more common than the giant variant and is said to produce two calves by the time the giant variant had produced one (Otchere et al., 1999). The Ghana Shorthorn is a larger type, which is not a true dwarf Shorthorn. WASH produce little milk, but have good quality meat. It can also be used for traction. They are kept purely for beef. They produce good carcass of up to 55 percent dressed weight and of ex. cellent flavour. They are regarded as the indigenous cattle of Ghana (Stewart \& Jeffreys 1956) with a population between 599,000 (FAO 1991) and 738,000 (Rege 1999).

The WASH are tolerant of tropical diseases and parasites and do relatively well on poor quality feed. They are believed to be trypanotolerant (Trail et. al, 1984; Anyorikeya 1992; Aning et. al. 1999). In Ghana, dermatophilosis was particularly severe in "grade" stock, serious in Zebu cattle and had a devastating effect 
on exotic breeds and their crosses, but rarely fatal to WASH (Stewart 1930, 1942; Koney 1992; Aning et al. 1999). Otchere and his associates (1999) reported that the WASH is resistant to trypanosomosis and dermatophilosis. The indications, however, are that the WASH may succumb to trypanosomosis and may suffer from production and reproductive losses under severe trypanosome infection.

\subsection{Distribution of WASH Cattle and their Population Estimates}

Traditionally, the home of the WASH has been in the Upper and Northern Regions of Ghana; extending southwards into the Northern parts of the Ashanti Region. The WASH is, however, found in all ecological zones of the country with higher concentrations in the Upper East, along the Navrongo-Bolgatanga-Zebilla corridor; in the Upper West, around Bole, Wa, Lawra and Tumu and in many areas of the Northern Region particularly around Damango, Fulfulso, Savelugu and Demon-Chegbani as well as large areas in the Gushiegu-Karaga Districts. By this distribution the WASH is not limited to the savanna regions alone.

Otchere and his associates (1997) reported that cattle constituted, in relative proportions, about $25.5 \%$ of all animals produced in the Saboba-Chereponi District. They further reported the average holding size of cattle in the district as 20 with a range of 3 to 100 . On regional basis, Ahunu and Boa-Amponsem (2001) estimated average herd size for the WASH to range from 3.6 in the Volta Region to 56.0 in the Northern Region giving a national average WASH herd size of 29.9. The highest concentration of the WASH is in the three northern regions, which account for $74.4 \%$ of all WASH cattle in the nation. Table 1 shows the regional estimates of WASH and average herd size. 
Table 1: Regional Estimates \pm s.e. of WASH and Average Herd Size

\begin{tabular}{|l|c|c|c|c|c|c|}
\hline $\begin{array}{c}\text { Administrative } \\
\text { Region }\end{array}$ & $\begin{array}{c}\text { Average Number } \\
\text { in a Herd }\end{array}$ & \multicolumn{2}{|c|}{$\begin{array}{c}\text { Average Cattle } \\
\text { Herd Size }\end{array}$} & $\begin{array}{c}\text { Regional Population } \\
\text { estimate of WASH }\end{array}$ & $\begin{array}{c}\text { WASH as Pro- } \\
\text { portion of Re- } \\
\text { gional Cattle } \\
\text { Population }\end{array}$ \\
\cline { 2 - 7 } & $\mathbf{n}$ & Mean \pm s. e. & $\mathbf{n}$ & $\begin{array}{c}\text { Mean } \pm \mathbf{s .} \\
\mathbf{e}\end{array}$ & Mean $\pm \mathbf{s .}$ e. & $\mathbf{( \% )}$ \\
\hline UPPER EAST & 12 & $14.7 \pm 4.3$ & 12 & $13.9 \pm 3.9$ & $162414 \pm 6022$ & 75.64 \\
UPPER WEST & 10 & $21.9 \pm 5.3$ & 10 & $35.4 \pm 9.0$ & $155969 \pm 8666$ & 54.48 \\
NORTHERN & 9 & $56.0 \pm 11.7$ & 9 & $73.7 \pm 12.5$ & $205338 \pm 8325$ & 47.81 \\
BRONG AHAFO & 10 & $18.1 \pm 6.1$ & 10 & $43.4 \pm 10.0$ & $20856 \pm 1178$ & 41.70 \\
ASHANTI & 19 & $11.1 \pm 3.7$ & 19 & $45.5 \pm 5.8$ & $5393 \pm 272$ & 24.89 \\
EASTERN & 5 & $19.2 \pm 7.5$ & 5 & $94.0 \pm 19.2$ & $9480 \pm 874$ & 17.58 \\
WESTERN & 3 & $7.3 \pm 0.3$ & 3 & $19.0 \pm 3.5$ & $1851 \pm 307$ & 38.59 \\
CENTRAL & 10 & $27.3 \pm 21.5$ & 10 & $98.9 \pm 35.6$ & $2238 \pm 108$ & 2.74 \\
VOLTA & 8 & $3.6 \pm 1.6$ & 8 & $132.1 \pm$ & $3098 \pm 564$ & 20.38 \\
GREATER AC- & 11 & $14.5 \pm 7.8$ & 11 & 35.6 & $13879 \pm 973$ & \\
CRA & & & & $71.4 \pm 10.9$ & & $\mathbf{4 6 . 5 6}$ \\
\hline
\end{tabular}

Source: Ahunu and Boa-Amponsem, 2001

The data presented by Ahunu and Boa-Amponsem (2001) showed that WASH now constituted $46.56 \%$ of the national cattle herd. These data have given greater support to the earlier call by the CSIR - ARI for the conservation of the WASH.

\subsection{Cattle Ownership and Inheritance}

WASH is the breed of cattle kept in the southern parts and other Konkomba areas of the Saboba-Chereponi District. Cattle are kept with the family head and the entire family has a collective responsibility for investing in them, guaranteeing their existence, and ensuring that investments yield dividends. Ownership of cattle in the district is tied to the culture of the area. In its broadest form, the head of a family is the 'owner' of all the cattle. Closely tied to the issue of ownership is the issue of inheritance. The family head is the oldest surviving member of a family. A young man within a family cannot be said to own cattle while a family head is alive. What a young man purchases is handed over to the old man. The owner needs to obtain permission from the family head in the event of a sale. The inheritance of a man's cattle also means the inheritance of his responsibilities (Millar et. al. 1998). 


\subsection{WASH Acquisition and Disposal}

Cattle are acquired mainly through inheritance, purchase, or gifts from maternal uncles and friends. WASH disposal methods include sales, slaughter during funerals, sacrifices and exchange of males for females. This underscores the economic and socio-cultural role of the WASH in particular and cattle in general in this society. Catthe are sold directly from the kraal. The decision to sell is the prerogative of the landlord. However, consultation is done among family members before disposal is effected. The consultation is indicative of the high value accorded cattle and to ensure that cattle are disposed off based on necessity. It could also be based on family respect and fostering of family unity.

\subsection{WASH: A Farmer Breed Preference}

The WASH is the breed of cattle kept in the southern parts and other Konkomba areas of the Saboba-Chereponi District. The farmers explained that they were hardier, adapted better to the environment and need little input to survive (Otchere et al. 1997). Similarly, Ahunu and Boa-Amponsem, (2001) reported that many cattle rearers, for example the Lobi, the Konkomba and the Chokosi treasure WASH cattle above all other breeds.

Otchere and his associates (1999) had reported that the WASH is the breed of choice in the Lawra District in the Upper West Region. The reasons for the preference of the WASH have been summarized in Otchere et. al. (1997), Otchere et. al.(1999) and Ahunu and BoaAmponsem (2001). These are as follows:

1. WASH can survive on little food and water during the long dry season.

2. WASH is resistant to disease and needs minimum veterinary care.

3. WASH is very fertile and calves regularly on yearly basis. Early maturing, age at first calving reputed to be between 3 4 years compared to $4-5$ years in the Zebu.

4. WASH is affordable for the payment of dowry and for starters who do not have much capital. 
5. Strong traditional ties with the Lobi and the Konkomba. One group of farmers put it this way: "it is the breed our ancestors kept and it served them well therefore we would like to continue with it."

6. The farmers are more conversant with the husbandry of WASH.

7. The meat of WASH is very tasty compared to that of the Zebu.

The advantages of using indigenous breeds are that they are readily available and are acclimatised to the local environment and possess desirable genetic traits associated with their acclimatisation. WASH adaptation to sparse forage and low rainfall conditions, trypanotolerance and tolerance to tick-borne diseases ensure low drug bills in poorly resourced farming communities. These are advantages, which make the WASH a preferred breed by smallholder farmers.

\subsection{WASH - An Excellent Source of Animal Power}

Otchere and his associates (1999) noted that farmer preference for the WASH as an excellent source of animal power could be harnessed to reduce the drudgery within rice growing valleys. The WASH was said to have the ability to keep going even when tired. The WASH ploughed slowly but kept going for longer hours than the Zebu. The farmers have realized the importance of animal traction. Some have been trained by ARI and were seriously engaged in using bullocks for land cultivation. Others hire bullockploughing services and were willing to own bullocks provided they got implements. One of the farmers at Nasom exchanged his heifer for one of the bulls kept at the ARI Chegbani station to use for ploughing. All castrates (bullocks) at Konkonzoli and Sambuli were used for ploughing (Zuri 2003). Farmers also used entire males for ploughing. Animal traction has so far helped them to cultivate large areas of land, plant early and earn high crop yields.

\subsection{Benefits of Keeping WASH as Perceived by Farmers}

The study revealed that farmers in the study area derive great bene- 
fits from raising WASH. A summary of some of the benefits ranked according to order of importance in the various locations is provided in Table 2.

Table 2: Ranked Order of Benefits of Keeping WASH by WASHBA Groups

\begin{tabular}{|l|l|}
\hline \multicolumn{1}{|c|}{ VILLAGE /WASHBA GROUP } & \multicolumn{1}{c|}{ BENEFITS } \\
\hline Chegbani and Kuntuli & Manure $>$ Milk $>$ Money $>$ Meat \\
\hline Konkonzoli & Milk $>$ Manure $>$ Money $>$ Meat \\
\hline Nasom & Manure $>$ Money $>$ Milk $>$ Meat \\
\hline Sambuli & Money $>$ Manure $>$ Meat $>$ Milk \\
\hline
\end{tabular}

Source: Field Survey

For the study location, weighted ranking on a 4 (max) to 1 (min) scale revealed the ranked order of benefits by the communities to be (14) Manure $>$ (11) Money $>$ (10) Milk $>$ (5) Meat. The positive implications for agricultural development will be the push forintegrated systems using the manure and the market oriented drive for cash from sales.

\subsection{Wealth Accumulation and Diversification}

The WASH forms the basis of savings within the Saboba-Chereponi District. All excess cash acquired through the sale of extra farm produce was converted to cattle. The concept of depreciation was well understood with an illustration from a young man in a Konkomba village who said using his money to buy a bicycle would give him less money over time but putting it into a cow would cause the money to multiply. An example of this was seen at Namiri Zongo where a farmer purchased a grinding mill from the sale of cattle. In both the Konkomba and Chokosi communities, WASH cattle are a source of wealth accumulation and a stabilising factor in the sociocultural organisation of the communities. They serve as a binding force, subject of continuity and a vital linkage even between the living and the dead (Millar et al. 1998). 


\subsection{Indigenous Groups, Associations and WASH Management}

Four main group types can be distinguished between the Konkomba and Chokosi tribes of the Saboba-Chereponi District. These include family groups, made up of nuclear and extended families; groups around Fulani herdsmen where the community come together to give their animals to Fulani herdsmen; activity groups, which are formed principally to undertake a specific job such as weeding someone's farm or building a new house. Communal labour is a rally point, even in villages with mixtures of ethnic groups. The last group type is externally motivated with some kind of facilitator, e.g. literacy classes or bullock traction, where the trainer was the central point. With cattle rearing, groupings around the Fulani were of relevance (Millar et al., 1998). Groupings around the Fulani had contractual relationship between stakeholders and the Fulani man completely devoid of integration. Normally, the Fulani are paid in kind. They receive a certain quantity of cereals, sell the milk from the cows and use the manure from the cattle. Payment of Fulani herders in kind had been reported on the Accra Plains (Hill, 1964; Otchere, 1966).

Within the family type of grouping, younger sons of the cattle owner watch the animals during grazing and watering. At night the cattle were kraaled either close to the Fulani compound, or the owner's compound or inside the compound. Group herding whereby several herds are grouped together is a common practice. The alliance with the Fulani can best be described as an uneasy symbiosis. Otchere and his associates (1997) observed that formal group formation and associations were not common in the SabobaChereponi District. This seemed to stem from lack of trust in one another. The few existing groups included the Amasachina at Demon and Sambuli Catholic Church Christian Mothers Association, though these had no bearing on the management of WASH. However, for the conservation and improvement of WASH cattle, there now exists WASHBA in and around the Chegbani (Konkomba) 
area. This is as a result of the WASH conservation and improvement efforts by the CSIR - ARI.

\subsection{Communities take over WASH Development in WASHBA Groups Formation}

In 1995, the MoFA adopted the ONBS for animal breeding by Ahunu and his associates (1995). MoFA's decision was based on the fact that cattle herds in Ghana were generally small and basic infrastructure for recording of performance and pedigree were nonexistent. It had been demonstrated by James (1977) and Kiwuwa (1992) that the use of ONBS allows for greater genetic gain in comparable conditions as exist in Ghana. The WASH is the dominant cattle breed in Ghana. Rege and his associates (1994) point out that the biggest threat to the WASH is from the numerically strong but ill-adapted Zebu, found in West African sub-region, which results from crossbreeding, is eroding the WASH genes. This has led to a reduction in the population of WASH in Ghana. According to Ahunu and Boa-Amponsem (2001) the WASH now constitutes only about $46 \%$ of the national herd (Table 1).

MoFA granted ARI the right to use the erstwhile Demon Cattle Ranch for research purposes in the early 1990s. The ARI, supported by the Saboba-Chereponi District Assembly, decided to use the station for research into the conservation and improvement of the WASH. The strategy adopted by ARI was the nationally accepted ONBS and through community participation for the formation of WASHBA. In pursuance of their objective, ARI facilitated the formation of these groups with the view of conserving and improving the WASH as well as alleviating rural poverty. The District Assembly gave moral, political and some amount of financial support to ARI for the purpose. Executives namely Chairman, Vice Chairman, Secretary, Organising Secretary and Treasurer lead all the groups. They operate by holding regular monthly meetings 
to discuss matters of common interest to boost production and promote development. Each member contributes $\mathfrak{c} 5.000$ per month. A major portion of the money is banked while part is used to purchase drugs for treating sick animals. Owners of treated animals pay a small amount. which is saved toward the restocking of drugs. The ARI Senior Technical Officer (STO) at Chegbani station. in addition to other assignments, is kept busy always buring drugs and treating their animals.

WASHBA Kuntuli saves their money with Bonzali Rural Bank. Yendi: WASHBA Chegbani saves with Ghana Commercial Bank. Yendi: while Konkonzoli. Nasom and Sambuli WASHBAs save with Agriculture Development Bank. Tamale. Members explained that the sared money serves as security against any erentuality and also as a guarantee for accessing loans credit facilities. The WASHBA groups have a bright future in achiering sustainable increased agriculture production due to the high enthusiasm and commitment of the groups members. Howerer. some of the groups are expecting relatively high financial and infrastructural suppon from ARI indicating that they have not fully grasped the essence of WASHBA. It is therefore needful for ARI to enlighten them further and also organize educational and training workshops seminars for them. Also. it is important for both gorermmental and non-governmental organizations to recognize WASHBA as a strategic partner in fighting rural poverty and for that matter support and motivate them. They should also see group formation as a strategy for viable economic and sustainable cattle derelopment.

Presently, there are tive (5) WASHBA groupings in the stud. location. each with a membership of ahout $15-20$ persons. Table: gives a summary of the groups showing year of existence and factors, which intluenced their formation. 
Table 3 Existing community-based WASHBA Groups

\begin{tabular}{|c|c|c|c|}
\hline $\begin{array}{c}\text { Name of } \\
\text { Group }\end{array}$ & $\begin{array}{c}\text { Year } \\
\text { Formed }\end{array}$ & $\begin{array}{c}\text { Own Bank } \\
\text { Account }\end{array}$ & Trigger factors (s) \\
\hline $\begin{array}{l}\text { W A S H B A } \\
\text { Chegbani }\end{array}$ & 1998 & Yes & $\begin{array}{l}\text { First of such group in the District. } \\
\text { Sensitization from study (Millar et al., } \\
\text { 1998) on group formation } \\
\text { Successful trials on-farm on effective } \\
\text { utilization of manure in collaboration } \\
\text { with ARI. }\end{array}$ \\
\hline $\begin{array}{l}\text { W A S H B A } \\
\text { Sambuli }\end{array}$ & 1999 & Yes & $\begin{array}{l}\text { Self realization to embrace agricultural } \\
\text { Innovations after participating in training } \\
\text { on compost making organized by ARI } \\
\text { Initiating role was played by Mr Bakela- } \\
\text { tob Nafori (now Chairman) of group }\end{array}$ \\
\hline $\begin{array}{l}\text { W A S HBA } \\
\text { Konkonzoli }\end{array}$ & 2001 & Yes & $\begin{array}{l}\text { Keenly followed events at Chegbani from } \\
\text { 1998-2001. } \\
\text { Invited ARI station for briefings. } \\
\text { Held meeting discussed and resolved to } \\
\text { form group to help increase their agricul- } \\
\text { tural productivity. }\end{array}$ \\
\hline $\begin{array}{l}\text { W A S H B A } \\
\text { Kuutuli }\end{array}$ & 2002 & Yes & $\begin{array}{l}\text { Initially part of the Chegbani groups. } \\
\text { Increasingly convinced of taking own } \\
\text { decisions after gains in high yields after } \\
\text { successful training on composing by ARI } \\
\text { staff. }\end{array}$ \\
\hline $\begin{array}{l}\text { WASHBA } \\
\text { Nasoan }\end{array}$ & 2002 & & $\begin{array}{l}\text { A farmer (now Chairman) visited Kon- } \\
\text { konzuli and witnessed WASHBA meet- } \\
\text { ing. } \\
\text { Feed back to community led to } \\
\text { WASHBA formation }\end{array}$ \\
\hline
\end{tabular}

Source: Field Survey 


\subsection{Gender and WASHBAs}

The average age of the farmers was between $30-50$ years. Both the young and the old engage in the rearing of cattle. Majority of cattle keepers were, however, above 30 years of age. This could be due to the fact that those within this age bracket are married and therefore keep cattle to help them look after their families. All 38 farmers interviewed at kraals were males and all 72 farmers met in participatory group discussions were males except one who was a female member at Sambuli. However, Nasom WASHBA has 3 female members who were absent during the discussions. Earlier reports had indicated that cattle production in the district is the domain of men (Otchere et al. 1997; Millar et al. 1998). This was because it is a taboo for women in the district to own livestock when they are still in their reproductive years. As a result married women who own animals keep them with their brothers and other relatives.

\subsection{Experiences of WASHBA for Improved Groups Dynamics}

Togetherness, understanding and unity are essential for the smooth and progressive running of any group of people be it family, sociocultural, economic or political. Set goals and objectives can neither stand nor be achieved without these. WASHBA groups operate in togetherness, understanding and unity aimed at attaining higher productivity. All the Association members interviewed agreed that the following united them:

$>$ WASH keeping and improved animal productivity as a result of WASHBA formation and enlightenment from ARI staff.

$>$ Love and communality of opinion (one farmer said they are drawn closer in love as they see that their animals are doing well).

$>$ Regular meetings on improving animal health and their agricultural productivity as well as adopting measures to control their animals from destroying crop fields.

$>$ Communal labour.

$>$ Funeral gatherings. 


\subsection{Perceived Benefits of the Association to the Members for Food Production and Breed Development}

The farmers enumerated benefits gained from WASHBA. Formation of Cattle groups or associations could be vital to sustainable food production and breed development and need to be embraced by smallholders. The farmers enumerated the following benefits from the Association:

$>$ Through the Association, they now experience low animal mortality and generally improved WASH productivity.

$>$ They used to travel long distance for veterinary service but they now have ARI at their doorsteps working together with them to take proper care of their animals.

$>$ They contribute money to buy drugs and take good care of their animals.

$>$ ARI, in 2002, vaccinated dogs and cats against rabies and based on the positive results they now organize to meet subsequent costs of the vaccines.

$>$ Members are more united and get ready access to communal labour. Members get help in cash or kind. Members can borrow money from the Association.

$>$ They now utilize manure efficiently and also make compost thereby gaining high crop yields (one farmer remarked, they used to get small corn cobs but now they get big cobs from their farms).

$>$ They were trained on bullock ploughing by the staff at ARI, Chegbani and they use them for timely land preparation and planting.

$>\quad$ The farmers at Nasom said the three women members among them spread educational messages fast in the village.

\subsection{Matching development coping strategies with production constraints}

Notwithstanding the perceived benefits enumerated by WASHBA members, matching the coping strategies with the identified and ranked constraints reveals that more remains to $b_{2}$ achieved by the WASHBA and the development partners in addressing the per- 
ceived constraints. The WASHBA groups perceived production constraints are presented in Table 4.

Table 4: WASHBA production constraints and coping strategies

\section{Ordered CONSTRAINTS}

Diseases, high cost and inadequate supply of drugs were ranked as the first limitation to WASH production in all the locations surveyed except Nasom which had the major constraint to be water during the dry season.

Food insecurity (poverty) and lack of credit

\section{COPING STRATEGIES}

1 WASHBA members are contributing money to buy drugs for treating sick animals.

2 They are in constant touch with ARI, Chegbani station for support.

3 They aiso apply indigenous (herbal) treatment to treat animal sickness using dawadawa, neem and pawpaw preparations.

1 Some of the farmers adopt composting for improved crop yields.

2. Some of farmers have started utilizing bullock ploughing for improved crop yield.

3 WASHBA members stand firm in unity and help each other communally and otherwise.

Lack of organized cattle markets in the None area resulting to marketing problems

Dry season feed shortage

None

Dry season water shortage

None

Rainy season flooding and inaccessible None roads

Lack of shelter (inadequate housing) for Some farmers house animals in halls animals

Inadequate veterinary coverage

They are in constant touch with ARI, Chegbani station for support

Lack of implements and a pair of bullocks 1 Some of farmers have started utilizing to utjlize bullock traction. bullock ploughing.

2 The few farmers owning impleinents and pairs of bullocks hire out their services at cost to the other farmers.

Source: Field Survey 


\subsection{Conclusion}

WASHBA members were aware of the constraints that hamper their production. They believed that their standard of living would improve drastically if the above constraints were addressed accordingly. They evolved the above coping strategies in order to subsist through the numerous constraints. This is most probably as a result of the WASHBA group formation. Thus, group formation is an effective tool to communication of improved technologies and technology adoption. The absence of coping strategies to address road and livestock market infrastructure as well as the seasonal inadequacy of feed and water will require immediate intervention by the District Assembly and its line agencies.

Indeed, both financial and technical support will be required from local and international development partners in order to sustain the Research and Development process in the Saboba-Chereponi District. Animal breed development requires long-term investments, materials, equipment and the human resource. The communities have identified themselves with the WASH cattle breed for good reasons and gone ahead to form WASHBA and any investment in this wise will not be a waste. 


\section{REFERENCES}

Adu, J.K., Karbo, N., Addo-Kwafo, A. and Otchere, E.O. (1999). Integrating the West African Shorthorn (WASH) cattle into the crop-livestock systems in the Northern Guinea Savannah: The role of WASH in sustainable soil fertility management in SabobaChereponi District, Northern Region. Technical Report of the Animal Research Institute (Unpublished).

Ahunu, B. K. and Boa-Amponsem, K (2001). Characterization and Conservation of the Ghana shorthorn cattle. Accra: Animal Production Directorate.

Ahunu, B.K.; Boa-Amponsem, K.; Okantah, S.A., Aboagye; G.S. \& Boadu, M.K. (1995). Animal Breeding Plans for the Republic of Ghana. Report Submitted to the Ministry of Food and Agriculture. Ministry of Food and Agriculture, Accra. (Unpublished)

Aning, K.G., Karbo, N., Doku, C.K. and Otchere, E. O. (1999). Dry season tsetse, Trypanosomosis and Dernatroplilosis Survey in the Saboba-Chereponi District of the Northern Region of Ghana. Technical Report of the Animal Research Institute, Accra (Unpublished).

Anyorikeya, T.A. (1992). Estimation of Health and production parameters in station-managed Cattle in Northern Ghana. A thesis submitted in partial fulfillment of the requirements for the degree of Master of Science in the Development of Animal Health and Production Programmes in the Department of Agriculture, Veterinary Epidemiology and Economics Research Unit. University of Reading, England (Unpublished).

District Planning Co-ordinating Unit (DPCU). (2002). Saboba - Chereponi District Development Plan. Saboba-Chereponi District Assembly, Northern Region, Ghana(Unpublished).

Food and Agriculture Organization (FAO) (1990). Cattle Breeding in the Tropics. Rome, Italy: FAO.

Hill, Poly. (1964). A socio-economic report on cattle: ownership and Fulani herdsmen in the Ashaiman/Dodowa district of the Accra Plains. (Unpublished mimeo).

James, J.W. (1977). Open Nucleus Breeding Schemes. Animal Production 24, pp. 287-305. 
Kiwuwa, G.H. (1992). Breeding Strategies for Small Ruminant Productivity in Africa. In Small Ruminant Research and Development (eds). Proceedings of $I^{s t}$ Biennial Conference of the African Small Ruminant Research Network, ILRAD, Nairobi, Kenya.

Koney, E.B.M. (1992). Livestock production and health in Ghana. Accra, Ghana: Adventist Press.

Millar, D., Karbo, N., Bruce, J. and Otchere, E. (1998). Group Formation and WASH Cattle Development among the Konkombas and Chokosis of the Northern Region. Technical Report of the Animal Research Institute, Accra, Ghana (unpublished).

Otchere, E.O. (1966). Preliminary observations on milk production among the Fulanis on the Accra Plains. B.Sc. (Agric.) Dissertation. Legon, University of Ghana Library (Unpublished).

Otchere, E.; Karbo, N.; Addo-Kwafo, A.; Aning, K.G.; Aboe, P.; Clottey, V.A.; \& Asare, G. (1997). Livestock Systems Diagnostic Survey: Saboba-Cherponi District, Northern Region. Technical Report of the Animal Research Institute, Accra, Ghana (unpublished).

Otchere, E. O.; Karbo, N.; Bruce, J.; Addo-Kwafo, A.; OseiSomuah, A.; Millar, D.; Clottey, V.A. \& Alenyorge, B. (1999). Livestock systems diagnostic survey: Lawra District, Upper West Region, Ghana. Technical Report of the Animal Research Institute, Accra, Ghana (unpublished).

Rege, J. E. O. (1999). The state of African Cattle genetic resources. I Classification framework and identification of threatened and extinct breeds. AGRI, 25, pp.1-25.

Rege, J. E. O., Aboagye, G.S. \& Tawal, C.L. (1994). Shorthorn cattle of West and Central Africa. I. Origin, Distribution, Classification and Population Statistics. World Animal Review,.78 (1), pp. 2-13.

Trail, J.C.M; Murray, M. \& Wissocq, Y. (1984). The mypanotolerant Livestock network in West and Central Africa - International Livestock Center for Africa (ILCA). ILCA Bulletin 18, pp. $16-19$.

Stewart, J. L. (1930). Streptothricosis. Report of the Veterinary Department for the year 1929-30, Gold Coast now Ghana (unpublished). 
Stwart, J.L. (1942). Report on the Department of Animal Health. Gold Coast. Government Printer, Accra.

Stewart, J. L. and Jeffreys, M. D.W. (1956). The cattle of the Gold Coast. Government Printer, Accra.

Zuri, M.B.T. (2003). Management and productivity of West African Shorthorn cattle in the West African Shorthorn Breeders Associations herds in the Saboba-Chereponi District, Northern Region, Ghana. B.Sc. (Agric. Tech) Dissertation, University for Development Studies, Tamale (Unpublished). 